\title{
Ocena rządowego projektu ustawy o dokumentach publicznych (druk sejmowy nr 2153) ${ }^{1}$
}

\begin{abstract}
Evaluation of the government bill on public documents (Sejm's paper no. 2153): In the aspect of compatibility with the UE law it has been pointed out that to the extent the project aims to exclude certain categories of prints and documents from the regulation of Directive 2014/24, it may be considered incompatible with this directive. It was recommended to suspend work on the bill until the CJEU delivers its judgment concerning case C-187/16. Furthermore in the aspect of compatibility with the rules of criminal procedure it was considered that the advantage of the proposed normative solution of Article 40 para. 3 is the pragmatic linking of access to evidence with the principles of procedural economy, i.e. the guarantee of access to material evidence is conditioned by the objectives of the criminal proceedings.
\end{abstract}

Keywords: documents | bill | EU law | public procurement | criminal procedure Słowa kluczowe: dokumenty | projekt ustawy | prawo UE | zamówienia publiczne | procedura karna

* Asystent w Instytucie Wymiaru Sprawiedliwości, ekspert ds. legislacji BAS; pawel.bachmat@sejm.gov.pl.

* Doktor nauk prawnych; adiunkt na Uniwersytecie Kardynała Stefana Wyszyńskiego, ekspert ds. prawa europejskiego i międzynarodowego BAS; marek.jaskowski@sejm.gov.pl.

\section{Przedmiot opinii}

Opinia dotyczy rządowego projektu ustawy o dokumentach publicznych (druk sejmowy nr 2153), a szczególnie:

- zgodności art. 17-21, art. 62, art. 64, art. 69 i art. 70 opiniowanego projektu ustawy z prawem Unii Europejskiej,

1 Opinia prawna dotyczaca rządowego projektu ustawy o dokumentach publicznych (druk sejmowy nr 2153) sporządzona 26 lutego 2018 r. na zlecenie przewodniczącego Komisji Administracji i Spraw Wewnętrznych; BAS-WAP/WAPM 284/18. 
- zgodności art. 40 ust. 3 i 4 opiniowanego projektu ustawy z regułami postępowania karnego.

Autorzy skoncentrowali się przede wszystkim na obszarach budzących wątpliwości co do zgodności z prawem UE oraz regułami postępowania karnego.

\section{Ocena projektu}

\section{Ocena dotycząca zgodności art. 17-21, art. 62, art. 64, art. 69 i art. 70 rządowego projektu ustawy o dokumentach publicznych (druk nr 2153) z prawem Unii Europejskiej}

\section{- Przedmiot opiniowanych przepisów}

Artykuł 17 projektu przewiduje, że blankiety dokumentów publicznych, o których mowa w art. 5 ust. 2 projektu, mają być wytwarzane przez jednoosobową spółkę Skarbu Państwa (dalej: Spółka), której przedmiotem działalności jest wytwarzanie blankietów dokumentów i druków zabezpieczonych, mającą siedzibę oraz zakład produkcyjny, w którym są wytwarzane blankiety dokumentów publicznych, na terytorium Rzeczypospolitej Polskiej. Artykuł 5 ust. 2 projektu zawiera wyliczenie dokumentów publicznych kategorii pierwszej, tj. w myśl ustawy dokumentów najistotniejszych z punktu widzenia bezpieczeństwa państwa. Jest to obszerny katalog obejmujący ponad 40 pozycji. Zgodnie z art. 17 ust. 6, jeżeli wytworzenie przez Spółkę blankietów dokumentu publicznego, o którym mowa $\mathrm{w}$ art. 5 ust. 2, zgodnie $\mathrm{z}$ warunkami określonymi przez emitenta dokumentu publicznego nie jest możliwe, blankiety tego dokumentu publicznego mogą być wytwarzane przez inny podmiot, mający świadectwo bezpieczeństwa przemysłowego pierwszego stopnia oraz zakład produkcyjny, w którym będzie wytwarzany blankiet tego dokumentu publicznego, na terytorium Rzeczypospolitej Polskiej.

Jednocześnie art. 64 projektu, przez zmianę art. 4 ust. 5c ustawy z 29 stycznia 2004 r. - Prawo zamówień publicznych (dalej: u.p.z.p.), zmierza do modyfikacji katalogu zamówień, do których nie stosuje się ustawy - Prawo zamówień publicznych. Zgodnie z obecnym brzmieniem tego przepisu ustawy - Prawo zamówień publicznych nie stosuje się do zamówień dotyczących wytwarzania i dystrybucji dokumentów publicznych (i ich personalizacji), druków o strategicznym znaczeniu dla bezpieczeństwa państwa oraz znaków akcyzy. Zgodnie z projektem przedmiotowe wyłączenie miałoby obejmować zamówienia dotyczące wytwarzania i personalizacji lub indywidualizacji dokumentów wymienionych w art. 5 ust. 2 opiniowanego projektu, a ponadto zamówienia dotyczące wytwarzania znaków akcyzy, znaków legalizacyjnych i nalepek kontrolnych, kart do głosowania, znaków holograficznych umieszczanych na zaświadczeniach o prawie do głosowania, a także układu mikroprocesorowego z oprogramowaniem służącym do zarządzania dokumentami publicznymi, systemów i baz informa- 
tycznych niezbędnych do zastosowania dokumentów publicznych, o których mowa w art. 5 ust. 2 projektu. Należy zaznaczyć, że zgodnie z obowiązującym stanem prawnym wykaz dokumentów publicznych i druków o strategicznym znaczeniu dla bezpieczeństwa państwa jest określany przez Radę Ministrów w drodze rozporządzenia (art. 4aa u.p.z.p. - przepis ten ma zostać uchylony na mocy art. 64 pkt 2 opiniowanego projektu). Obecnie wykaz taki jest zawarty w rozporządzeniu Rady Ministrów w sprawie wykazu dokumentów publicznych i druków o strategicznym znaczeniu dla bezpieczeństwa państwa z 20 lipca 2016 r. (Dz.U. poz. 1089; 2017, poz. 1996). Projektowana zmiana polega więc na przeniesieniu tej regulacji na poziom ustawowy, jak również na poszerzeniu jej zakresu o niektóre dokumenty. Modyfikacje przewidziane w art. 62, 69 i 70 projektu zmierzają do uchylenia przepisów przyznających określonym w nich ministrom kompetencję w zakresie wyboru dostawców druków i usług i stanowią konsekwencję wskazanych wyżej zmian.

\section{- Stan prawa Unii Europejskiej w materii objętej projektem ustawy}

Oceny wskazanych przepisów projektu należy dokonać z uwzględnieniem dyrektywy Parlamentu Europejskiego i Rady 2014/24/UE z 26 lutego 2014 r. w sprawie zamówień publicznych, uchylającej dyrektywę 2004/18/WE (Dz.Urz. UE L 94 z 28 marca 2014 r., s. 65).

W myśl art. 1 ust. 1 dyrektywa 2014/24 ustanawia przepisy dotyczące procedur udzielania zamówień przez instytucje zamawiające $\mathrm{w}$ odniesieniu do zamówień publicznych oraz konkursów, których wartość szacunkowa jest nie mniejsza niż kwoty progowe określone $\mathrm{w}$ art. 4 dyrektywy. Zgodnie $\mathrm{z}$ art. 15 ust. 2 akapit 1 dyrektywy 2014/24 nie ma ona jednak zastosowania do zamówień publicznych i konkursów w stopniu, w jakim ochrona podstawowych interesów danego państwa członkowskiego $\mathrm{w}$ zakresie bezpieczeństwa nie może zostać zagwarantowana przez mniej inwazyjne środki, na przykład przez nałożenie wymogów mających na celu ochronę poufnego charakteru informacji udostępnianych przez instytucję zamawiającą $\mathrm{w}$ trakcie trwania postępowania o udzielenie zamówienia zgodnie z dyrektywą. Ponadto art. 15 ust. 2 akapit 2 dyrektywy 2014/24 potwierdza, że zgodnie z art. 346 ust. 1 lit. a TFUE ${ }^{2}$ nie ma ona zastosowania do zamówień publicznych i konkursów w stopniu, w jakim stosowanie tej dyrektywy zobowiązywałoby państwo członkowskie do dostarczania informacji, których ujawnienie państwo to uważa za sprzeczne z jego podstawowymi interesami w zakresie bezpieczeństwa.

Trzeba podkreślić, że dyrektywa 2014/24, jako stosunkowo nowy akt prawny, nie doczekała się dotychczas orzecznictwa równie bogatego, co uchylona na

2 Zgodnie z tym przepisem: żadne Państwo Członkowskie nie ma obowiązu udzielania informacji, których ujawnienie uznaje za sprzeczne z podstawowymi interesami jego bezpieczeństwa. 
jej mocy dyrektywa 2004/18. Niemniej należy zauważyć, że również dyrektywa 2004/18 przewidywała wyłączenie jej stosowania do zamówień publicznych określonych jako tajne, jeżeli ich realizacji musiały towarzyszyć szczególne środki bezpieczeństwa albo jeżeli wymagała tego ochrona podstawowych interesów tego państwa. W związku z tym orzecznictwo dotyczące uchylonej dyrektywy może pomocniczo stanowić wskazówkę przy interpretacji dyrektywy 2014/24. Podobnie należy traktować orzecznictwo Trybunału Sprawiedliwości Unii Europejskiej (dalej: TSUE) dotyczące wyjątków uzasadnianych koniecznością ochrony bezpieczeństwa państwa członkowskiego, w szczególności zgodnie $\mathrm{z}$ art. 346 TFUE.

Jeżeli chodzi o podstawowe interesy państwa w zakresie bezpieczeństwa, to należy wskazać, że pojęcie bezpieczeństwa publicznego odnosi się jednocześnie do wewnętrznego bezpieczeństwa państwa członkowskiego i jego bezpieczeństwa zewnętrznego. Wśród zagrożeń dla bezpieczeństwa publicznego TSUE wymienia zagrożenie dla funkcjonowania głównych instytucji i służb publicznych oraz życia ludności, ryzyko poważnego zakłócenia stosunków zagranicznych lub pokojowego współistnienia narodów bądź zagrożenie interesów wojskowych ${ }^{3}$, ale również niektóre rodzaje przestępczości o szczególnym nasileniu (np. obrót środkami odurzającymi w zorganizowanej grupie przestępczej ${ }^{4}$ ).

W odniesieniu do marginesu uznania, jakim dysponują państwa członkowskie wprowadzające odstępstwo, orzecznictwo TSUE nie jest spójne. Z jednej bowiem strony TSUE stoi na stanowisku, że odstępstwa od podstawowych reguł rynku wewnętrznego - w tym z uwagi na konieczność ochrony bezpieczeństwa publicznego - muszą podlegać wykładni zwężającej (chociaż w literaturze wskazuje się, że w praktyce interpretacja tych wyjątków bywa jednak dość szeroka $^{6}$ ). Z drugiej strony TSUE stwierdza, że w przypadku powołania się na podstawowe interesy bezpieczeństwa państwa członkowskie dysponują szczególnie szerokim zakresem uznania przy ocenie potrzeb wymagających takiej ochrony ${ }^{7}$. W każdym razie środki, które przyjmują państwa członkowskie w ramach słusznych względów interesu narodowego, nie są wyjęte z zakresu stosowania prawa wspólnotowego z tego tylko powodu, że są podejmowane w interesie bezpieczeń-

3 Wyrok TSUE (Wielka Izba) z 23 listopada 2010 r. Land Baden-Württemberg v. Panagiotis Tsakouridis, sygn. akt C-145/09, ECLI:EU:C:2010:708, pkt 43-44.

$4 \quad$ Ibidem, pkt 47.

5 Wyrok TSUE z 7 czerwca 2012 r. Insinööritoimisto InsTiimi Oy, sygn. akt C-615/10, EU:C:2012:324, pkt 35; wyrok TSUE z 16 września 1999 r. Komisja Wspólnot Europejskich v. Królestwo Hiszpanii, sygn. akt C-414/97, EU:C:1999:417, pkt 22 i 24.

6 S. Arrowsmith, The Law of Public and Utilities Procurement, London 2014, s. 503.

7 Wyrok Sądu pierwszej instancji z 30 września 2003 r. Fiocchi munizioni SpA v. Komisja, sygn. akt T-26/01, ECLI:EU:T:2003:248, pkt 58 (w odniesieniu do obecnego art. 346 ust. 1 lit. b TFUE). 
stwa publicznego lub obrony narodowej ${ }^{8}$. Przepisów takich nie można więc interpretować w taki sposób, jakoby państwom członkowskim przyznano prawo do ustanowienia wyjątków poprzez samo tylko powołanie się na przedmiotowe interesy. Państwo członkowskie powinno bowiem w takiej sytuacji nie tylko wykazać konieczność zastosowania wyjątku w celu ochrony istotnych interesów swojego bezpieczeństwa ${ }^{9}$, ale również - że potrzeba ochrony tych podstawowych interesów nie mogła zostać osiągnięta w trakcie postępowania przetargowego przewidzianego $\mathrm{w}$ dyrektywie ${ }^{10}$ oraz że wyłączenia nie wykraczają poza granice przewidziane prawem UE ${ }^{11}$. Ponadto podkreślić należy konieczność poszanowania przez państwo członkowskie zasady proporcjonalności przy określaniu odstępstw od reguł prawa UE ${ }^{12}$. W przypadku art. 15 ust. 2 dyrektywy 2014/24 należy podkreślić, że odnosi się on do podstawowych interesów państwa w dziedzinie bezpieczeństwa, co ogranicza zakres swobody uznania przysługujący państwom członkowskim przy stosowaniu tego przepisu.

\section{- Analiza przepisów projektu pod kątem ustalonego stanu prawa Unii Europejskiej}

1. W zakresie, w jakim projekt zmierza do wyłączenia określonych kategorii druków i dokumentów spod regulacji dyrektywy 2014/24, wymaga się uzasadnienia zgodnie z orzecznictwem TSUE przedstawionym powyżej.

W uzasadnieniu projektu wskazuje się, że zlecenie produkcji wymienionych dokumentów poza systemem zamówień publicznych umożliwi skuteczne sprawowanie przez państwo kontroli nad ich produkcją, przejawiające się m.in. w wyborze podmiotu spełniającego warunki bezpieczeństwa produkcji, określone w ustawie. Ponieważ powierzenie takiemu podmiotowi produkcji dokumentów będzie stanowiło rękojmię, że nie dojdzie do osłabienia bezpieczeństwa wewnętrznego i zewnętrznego państwa, włączenie wymienionych dokumentów do kategorii pierwszej dokumentów publicznych jest działaniem adekwatnym (s. 8 uzasadnienia projektu). Ponadto, zgodnie z uzasadnieniem projektu, powierzenie, co do zasady, produkcji najistotniejszych dokumentów publicznych podmiotowi kontrolowanemu przez państwo daje gwarancje wpływu państwa na poziom bezpieczeństwa tych dokumentów. Regulacja ta wraz z wyłaczeniem dokumentów pierwszej

8 Wyrok TSUE (Wielka Izba) z 8 kwietnia 2008 r. Komisja v. Włochy, sygn. akt C-337/05, EU:C:2008:203, w szczególności pkt 42-43.

9 Wyrok TSUE z 4 września 2014 r. Schiebel Aircraft, sygn. akt C-474/12, EU:C:2014:2139, pkt 34.

10 Wyrok TSUE z 7 czerwca 2012 r. Insinööritoimisto InsTiimi Oy, sygn. akt C-615/10, EU:C:2012:324, pkt 45.

11 Wyrok TSUE (Wielka Izba) z 8 kwietnia 2008 r. Komisja v. Włochy, sygn. akt C-337/05, EU:C:2008:203, w szczególności pkt 44.

12 Wyrok TSUE z 2 października 2008 r. Komisja v. Włochy, sygn. akt C-157/06, EU:C:2008:530, pkt 31. 
kategorii spod stosowania przepisów o zamówieniach publicznych (art. 64 projektu) umożliwi ochrone podstawowych interesów bezpieczeństwa państwa i bezpieczeństwa publicznego. Ponadto powierzenie produkcji dokumentów identyfikacyjnych Spółce ma służyć ochronie danych osobowych oraz bezpieczeństwu transakcji, przy których wykorzystywane są zabezpieczone dokumenty (s. 11-12 uzasadnienia projektu). Ponadto projektodawca wskazuje, że: proces wywarzania dokumentów publicznych oraz druków, o których mowa $w$ zmienianym art. 4 pkt 5c PZP [ustawa - Prawo zamówień publicznych], wymaga stosowania szczególnych procedur bezpieczeństwa, nie jest [więc] możliwe udzielanie $w$ odniesieniu do nich zamówień publicznych w oparciu o przepisy ustawy, w tym w oparciu o przepisy rozdziału 4a PZP, co uzasadnia wyłaczenie ich wytwarzania spod obowiązku stosowania PZP i jest zgodne $z$ art. 15 ust. 2 dyrektywy 2014/24/UE, w tym $z$ art. 346 ust. 1 lit. a TFUE (s. 21 uzasadnienia projektu).

$\mathrm{W}$ związku z przedstawionym uzasadnieniem nasuwają się następujące wątpliwości. Po pierwsze, katalog dokumentów, których wytwarzanie miałoby zostać wyłączone z zakresu regulacji dotyczących zamówień publicznych, zawiera dokumenty, których znaczenie dla ochrony podstawowych interesów danego państwa członkowskiego w zakresie bezpieczeństwa jest wątpliwe. Przykładowo, wydaje się, że dokumenty takie jak legitymacja dokumentująca niepełnosprawność lub stopień niepełnosprawności, prawo wykonywania zawodu lekarza i lekarza dentysty czy karta pojazdu trudno uznać za kluczowe z punktu widzenia bezpieczeństwa państwa, czy to bezpieczeństwa zewnętrznego, czy wewnętrznego.

Po drugie, podobne wątpliwości budzi wskazanie w uzasadnieniu ochrony danych osobowych oraz bezpieczeństwa transakcji jako podstawy powołania się na odstępstwo przewidziane w art. 15 ust. 2 dyrektywy 2014/24. Dyskusyjne jest bowiem powiązanie ochrony danych osobowych ${ }^{13}$ oraz pewności obrotu handlowego $\mathrm{z}$ podstawowymi interesami państwa członkowskiego w zakresie bezpieczeństwa, a w każdym razie uzasadnienie nie wskazuje na taki związek.

Po trzecie, art. 15 ust. 2 dyrektywy 2014/24 wyłącza jej zastosowanie jedynie w stopniu, w jakim ochrona podstawowych interesów danego państwa członkowskiego w zakresie bezpieczeństwa nie może zostać zagwarantowana przez mniej inwazyjne środki, na przykład przez nałożenie wymogów mających na celu ochronę poufnego charakteru informacji udostępnianych przez instytucję zamawiającą w trakcie trwania postępowania o udzielenie zamówienia zgod-

13 Poza tym należy podkreślić, że zgodnie z wyrokiem TSUE z 5 grudnia 1989 r. Komisja v. Włochy, sygn. akt C-3/88, ECLI:EU:C:1989:606, pkt 23, ochrona danych jako taka może być zapewniona poprzez nałożenie obowiązku zachowania poufności i nie wymaga tak daleko idących środków jak wykluczenie przedsiębiorstw z innych państw członkowskich, nie zależy też od publicznej formy własności przedsiębiorstwa przetwarzającego dane. 
nie $\mathrm{z}$ tą dyrektywą. Tymczasem uzasadnienie projektu w zasadzie nie odnosi się do tego wymogu. Nie wyjaśnia ono, jakie „mniej inwazyjne” rozwiązania alternatywne były brane pod uwagę i dlaczego projektodawca uznał je za niecelowe (np. z uwagi na niedostateczną skuteczność, nadmierny koszt, nadmierny stopień skomplikowania). W szczególności projektodawca nie odniósł się do wyrażonej wprost przez art. 15 ust. 2 dyrektywy 2014/24 możliwości polegającej na nałożeniu wymogów mających na celu ochronę poufnego charakteru informacji udostępnianych przez instytucję zamawiającą. Ponadto spójność projektowanych rozwiązań może zostać zakwestionowana $\mathrm{w}$ związku $\mathrm{z}$ treścią art. 17 ust. 6 projektu, który przewiduje możliwość wytworzenia dokumentu publicznego, o którym mowa $\mathrm{w}$ art. 5 ust. 2 projektu, przez inny podmiot, o którym mówi art. 18 projektu (spełniający określone w projekcie wymogi), gdyby wytworzenie go przez Spółkę zgodnie z warunkami określonymi przez emitenta okazało się niemożliwe. Zgodnie z uzasadnieniem: sytuacja, w której Spółka może nie być w stanie wytworzyć blankietów dokumentów publicznych pierwszej kategorii zgodnie z warunkami określonymi przez emitenta dokumentu publicznego (lub Krajową Radę Notarialna w przypadku zamawiania dokumentów notarialnych), może zaistnieć np. w przypadku braku możliwości realizacji przez Spólkę zamówienia na wytworzenie dokumentu publicznego w określonym przez emitenta terminie, liczbie lub cenie (s. 11 uzasadnienia projektu). Niespójność polega na tym, że projektodawca z jednej strony uważa wytwarzanie dokumentów przez Spółkę za konieczne z uwagi na ochronę podstawowych interesów państwa w zakresie bezpieczeństwa, z drugiej - przewiduje możliwość odstąpienia od tego rzekomo koniecznego ograniczenia, co więcej - z tak banalnego w tym kontekście powodu jak choćby cena wytworzenia dokumentu. Wobec powyższego zasadna wydaje się wątpliwość, czy wszystkie dokumenty nie mogłyby być wytwarzane przez inne podmioty, o których mowa w art. 18 projektu.

Podsumowując, należy stwierdzić, że w zakresie, w jakim projekt zmierza do wyłączenia określonych kategorii druków i dokumentów spod regulacji dyrektywy 2014/24, może on zostać uznany za niezgodny z dyrektywą 2014/24, w szczególności z art. $1 \mathrm{w}$ związku $\mathrm{z}$ art. 15 ust. 2.

2. W dołączonej do projektu ocenie skutków regulacji wskazuje się, że rozwiązania podobne do zawartych w projekcie obowiązują również w innych państwach członkowskich, w tym w Austrii. W związku z tym należy zwrócić uwagę, że zgodność obowiązujących w Austrii przepisów z prawem UE stanowi przedmiot postępowania przed TSUE ${ }^{14}$. $\mathrm{Z}$ uwagi na istotne podobieństwo niektórych rozwiązań austriackich i rozwiązań zawartych w opiniowanym projekcie, a także na argumenty podnoszone przez Austrię, uzasadnione jest bardziej szczegółowe przedstawienie aktualnego stanu tej sprawy.

14 Sprawa Komisja v. Austria, sygn. akt C-187/16. 
W skardze wniesionej 13 maja 2016 r. Komisja Europejska (KE) zarzuca Austrii naruszenie m.in. art. 4 w związku z art. 11-37 dyrektywy 92/50/EWG ${ }^{15}$ oraz art. 14, 20 i $23-55$ dyrektywy $2004 / 18 / W^{16} \mathrm{z}$ tego powodu, że państwo to udzieliło zamówienia na usługi w zakresie wytwarzania określonych dokumentów (jak paszporty z chipem, paszporty tymczasowe, dokumenty pobytowe, dowody osobiste, legitymacje pirotechnika, dokumenty prawa jazdy $\mathrm{w}$ formacie karty bankowej i dowody rejestracyjne w formacie karty bankowej) bezpośrednio spółce Österreichische Staatsdruckerei GmbH oraz utrzymało w mocy przepisy krajowe przewidujące względem instytucji udzielających zamówień publicznych obowiązek udzielania zleceń na usługi wyłącznie spółce Österreichische Staatsdruckerei GmbH. Należy podkreślić, że w toku postępowania poprzedzającego wniesienie skargi Komisja stopniowo wycofywała swoje zarzuty dotyczące kart motorowerowych, dowodów rejestracyjnych $\mathrm{w}$ formacie papierowym, patentów żeglarskich, formularzy dokumentów bezpieczeństwa i banderol akcyzowych $\mathrm{z}$ uwagi na to, że dokumenty te zostały częściowo zniesione, a częściowo ich produkcja była przedmiotem $\operatorname{przetargu}^{17}$. W toku postępowania poprzedzającego wniesienie skargi Austria powołała się na ochronę podstawowych interesów bezpieczeństwa krajowego. Ochrona informacji tajnych, zabezpieczenie autentyczności i prawidłowości danych dokumentów, bezpieczeństwo dostaw i zapewnienie ochrony danych wrażliwych uzasadnia, w ocenie Austrii, udzielanie zamówień na druk wyłącznie Staatsdruckerei. Jedynie bowiem Staatsdruckerei charakteryzuje się odpowiednimi środkami bezpieczeństwa w zakresie organizacji, stanu technicznego i budynków, aby wykonać to zamówienie. Wobec przedsiębiorstw innych niż Staatsdruckerei dochowanie wymogów bezpieczeństwa może być egzekwowane tylko za pomocą środków prawa cywilnego, natomiast wobec Staatsdruckerei organom państwowym Austrii przysługują z mocy ustawy szczególne uprawnienia kontrolne. Z kolei KE podkreśliła, że możliwe jest zorganizowanie publicznego przetargu w ten sposób, że mogą zostać uwzględnieni wyłącznie przedsiębiorcy specjalizujący się w wytwarzaniu dokumentów spełniających szczególne wymogi w zakresie zabezpieczeń i podlegający odpowiedniej kontroli.

15 Dyrektywa Rady 92/50/EWG z 18 czerwca 1992 r. odnosząca się do koordynacji procedur udzielania zamówień publicznych na usługi (Dz.Urz. UE L 209 z 24 lipca 1992 r., s. 1), uchylona na mocy dyrektywy 204/18.

16 Dyrektywa 2004/18/WE Parlamentu Europejskiego i Rady z 31 marca 2004 r. w sprawie koordynacji procedur udzielania zamówień publicznych na roboty budowlane, dostawy i usługi (Dz.Urz. UE L 134 z 30 kwietnia 2004 r., s. 114), uchylona na mocy dyrektywy 2014/24.

17 Zgodnie $\mathrm{z}$ informacją przedstawioną w tej sprawie przez rzecznik generalną J. Kokott (opinia z 20 lipca 2017 r., ECLI:EU:C:2017:578). 
Na dzień sporządzenia niniejszej opinii sprawa nie została jeszcze rozstrzygnięta przez TSUE ${ }^{18}$, natomiast 20 lipca 2017 r. wydana została opinia rzecznik generalnej J. Kokott (dalej: rzecznik) ${ }^{19}$. Odnosi się ona do trzech zasadniczych argumentów przedstawionych przez Austrię.

Po pierwsze, w ocenie Austrii, wymóg scentralizowanego wykonywania zamówień na druk przez jedno przedsiębiorstwo znajduje uzasadnienie w konieczności sprawowania przez władze kontroli prawidłowego wykonania zamówień z zachowaniem koniecznych środków zapewnienia tajemnicy i bezpieczeństwa. Ponadto centralizacja realizacji zamówień zmniejsza ryzyko, że osoby nieuprawnione zdobędą wiedzę o tych środkach bezpieczeństwa lub że wrażliwy materiał (np. druki paszportów lub dokumentów pobytowych) wpadną w ręce osób nieuprawnionych. W ocenie rzecznik: centralizacja wykonywania zamówień przyczynia się do ochrony podstawowych interesów w zakresie bezpieczeństwa, a nawet przyczynia się do ochrony danych. Niemniej jednak argument centralizacji może ostatecznie wyjaśnić jedynie to, dlaczego sporne zamówienia na druk jest udzielane zawsze tylko jednemu przedsiębiorstwu (a nie kilku przedsiębiorstwom jednocześnie). Natomiast powołując się na argument wymogu centralizacji, nie da się przekonujaco uzasadnić, dlaczego do ochrony podstawowych interesów $w$ zakresie bezpieczeństwa niezbędne ma być udzielanie zamówienia zawsze tylko temu samemu przedsiębiorstwu (pkt 57 opinii).

Austria podnosi również, że w świetle prawa austriackiego jej organy dysponują władczymi uprawnieniami kontrolnymi tylko w stosunku do Staatsdruckerei, nie zaś w stosunku do innych przedsiębiorstw, w szczególności zagranicznych.

Rzecznik zgadza się ze stanowiskiem, że stosowanie władczych uprawnień kontrolnych może być konieczne w celu ochrony podstawowych interesów w zakresie bezpieczeństwa krajowego, ponieważ są one bardziej skuteczne w działaniu niż prawa kontrolne uzgodnione w umowie cywilnoprawnej. Niemniej, jej zdaniem, ta okoliczność sama w sobie nie uzasadnia całkowitego pomijania istniejących wymogów prawa Unii w odniesieniu do udzielania zamówień publicznych i a priori brania pod uwage jako wykonawcę zawsze tylko jednego określonego przedsiębiorstwa. Zdaniem rzecznik Austria powinna zapewnić równowagę między uprawnieniami kontrolnymi koniecznymi dla ochrony bezpieczeństwa z jednej strony i swoimi zobowiązaniami unijnymi z drugiej strony, przy czym do dopuszczalnych rozwiązań rzecznik zalicza:

- zamiast całkowitego wyłączenia z przetargu przedsiębiorstw z siedzibą w innych państwach stronach porozumienia EOG Austria mogłaby w razie potrzeby zobowiązać wszystkich zainteresowanych do zrealizowania spornego zamówienia na druk w razie jego udzielenia przez zakład położony w kraju,

18 Zgodnie z kalendarzem TSUE, https://curia.europa.eu/jcms/jcms/Jo1_6581/pl, wydanie wyroku zostało zaplanowane na 20 marca $2018 \mathrm{r}$.

19 Opinia z 20 lipca 2017 r., ECLI:EU:C:2017:578. 
przetwarzania gromadzonych przy tym danych osobowych wyłącznie w kraju oraz nieprzesyłania takich danych oraz informacji dotyczących bezpieczeństwa przez zagraniczne linie danych lub serwery lub nieprzekazywania ich do części przedsiębiorstwa położonych za granicą lub zagranicznym władzom,

- oraz zamiast przewidywać uprawnienia kontrolne z zakresu władzy publicznej [...] wyłacznie wobec Staatsdruckerei, ustawodawca austriacki mógłby ogólnie upoważnić odpowiedzialne organy państwowe do przeprowadzania takich kontroli we wszystkich przedsiębiorstwach majacych zakłady $w$ kraju, jeżeli wykonują one tam istotne pod względem bezpieczeństwa zamówienia na drukowanie.

Wynikające $\mathrm{z}$ powyższego rozwiązania ograniczenia swobody przepływu usług byłyby, zdaniem rzecznik, dopuszczalne w świetle orzecznictwa TSUE ${ }^{20}$ z uwagi na konieczność przeprowadzania kontroli administracyjnych.

W końcu rzecznik generalna odnosi się do argumentu jakoby spornego zamówienia udzielono konkretnie Staatsdruckerei, ponieważ między tym przedsiębiorstwem i odpowiedzialnym organem państwowym istnieje szczególny stosunek zaufania. Jej zdaniem: byłaby ewidentnie sprzeczna $z$ istota europejskiego rynku wewnętrznego w ogólności i prawem zamówień publicznych w szczególności sytuacja, w której państwo członkowskie niemal dowolnie uznaje wyłacznie jedno przedsiębiorstwo, zwłaszcza swojego poprzedniego państwowego i obecnie sprywatyzowanego "historycznego" usługodawcę $w$ określonej dziedzinie, zgodnie z mottem „znany i sprawdzony” za szczególnie niezawodne i godne zaufania, natomiast innym przedsiębiorstwom a priori odmawia niezawodności i wiarygodności lub $w$ każdym razie podaje je $w$ watpliwość. Opierając się na orzecznictwie TSUE, rzecznik generalna podkreśliła, że konieczność ustanowienia obowiązku dochowania poufności nie wyklucza w żaden sposób zastosowania postępowania przetargowego przy udzielaniu zamówienia ${ }^{21}$. Unijne zasady udzielania zamówień publicznych pozostawiają bowiem instytucjom zamawiającym wystarczający zakres swobody dla niezbędnych środków bezpieczeństwa i dochowania tajemnicy we wrażliwej dziedzinie, czy to w postępowaniu aż do wyboru najbardziej odpowiedniego wykonawcy, czy też później w stadium wykonywania zamówienia.

Podsumowując, rzecznik generalna stwierdza, że: nic nie ogranicza instytucji zamawiających przy udzielaniu wrażliwych zamówień publicznych, takich jak zamówienia na [...] wytwarzanie dokumentów urzędowych, w stawianiu szczególnie wysokich wymagań co do kwalifikacji i niezawodności wykonawcy zamówienia,

20 Wyrok TSUE z 4 grudnia 1986 r. Komisja v. Niemcy, sygn. akt 205/84, EU:C:1986:463, pkt 52 w związku z pkt 54.

21 Wyrok TSUE (Wielka Izba) z 8 kwietnia 2008 r. Komisja v. Włochy, sygn. akt C-337/05, EU:C:2008:203, pkt 52; wyrok TSUE z 2 października 2008 r. Komisja v. Włochy, sygn. akt C-157/06 EU:C:2008:530. 
ustalaniu odpowiednio warunków przetargu oraz żądaniu od ubiegających się o zamówienie potrzebnych dowodów. Ponadto wykonawcy moga zostać zobowiązani do spetnienia warunków dotyczacych wykonania zamówień na drukowanie, które moga obejmować również środki wakresie ochrony danych, dochowania tajemnicy $i$ bezpieczeństwa, $w$ tym kontrolę bezpieczeństwa wszystkich pracowników uczestniczących przy wykonaniu zamówienia. To wszystko nie powoduje jednakże tego, że wytwarzanie dokumentów urzędowych staje się zamówieniem intuitu personae, które powinno być wykonane wyłącnie przez konkretna osobę (pkt 68 opinii).

$\mathrm{Na}$ uwagę zasługuje również argument podniesiony przez Austrię na rozprawie: zagraniczne przedsiębiorstwa nie mogą całkowicie uchylić się od ingerencji władz swojego kraju pochodzenia i częściowo są nawet zobowiązane do współpracy z tamtejszymi tajnymi służbami, i to także wówczas, gdy wykonują zamówienia publiczne za pośrednictwem zagranicznego zakładu. Dlatego takie przedsiębiorstwa nie mogą być brane pod uwagę jako wykonawcy wrażliwych zamówień na druk, takich jak te sporne w niniejszej sprawie. Również ten argument nie przekonał rzecznik, warto jednak podkreślić jej uzasadnienie. Otóż $\mathrm{w}$ jej opinii: [z]godnie $z$ utrwalonym orzecznictwem przepisy krajowe sq odpowiednie do zapewnienia osiagnięcia zamierzonego celu jedynie wtedy, gdy rzeczywiście odzwierciedlają zamiar osiagnięcia tego celu w sposób spójny i systematyczny. W niniejszym wypadku Austria, o ile wiadomo, nie podjęła żadnych środków, które skutecznie mogłyby uniemożliwić, aby Staatsdruckerei dostała się pod kontrole zagranicznych wspólników lub stała się spótka zależna zagranicznej osoby prawnej. Państwo austriackie nie wynegocjowało sobie $w$ Staatsdruckerei motywowanych względami polityki bezpieczeństwa uprawnień do współdecydowania $w$ formie szczególnej akcji („złota akcja”), ani nie poddało zbywania udziałów w Staatsdruckerei żadnym ograniczeniom ze względów polityki bezpieczeństwa. Na podstawie tego stanowiska można wnioskować a contrario, że wprowadzenie tego rodzaju ograniczeń uniemożliwiających przejęcie kontroli nad spółką, o której mowa w art. 17 ust. 1 projektu, stanowiłoby argument przemawiający za zgodnością projektu z dyrektywą 2014/24.

Zważywszy na znaczenie rozstrzygnięcia w przedmiotowej sprawie dla oceny zgodności opiniowanego projektu z prawem UE, zaleca się zawieszenie prac nad projektem do czasu wydania wyroku przez TSUE (planowana data wydania wyroku: 20 marca 2018 r.).

\section{Ocena dotycząca zgodności art. 40 ust. 3 i 4 rządowego projektu ustawy o dokumentach publicznych (druk sejmowy nr 2153) $z$ regułami postępowania karnego}

\section{- Przedmiot opiniowanych przepisów}

Opiniowany projekt przewiduje uregulowanie dostępu upoważnionych członków Komisji do spraw dokumentów publicznych do dowodów rzeczowych w po- 
staci sfałszowanego dokumentu publicznego w trakcie trwającego postępowania karnego oraz po jego prawomocnym zakończeniu. Stosownie do art. 40 ust. 3 projektu organ dysponujący dowodem rzeczowym w postaci sfałszowanego dokumentu publicznego umożliwia upoważnionemu członkowi Komisji dostęp do tego dowodu rzeczowego, a po prawomocnym zakończeniu postępowania karnego przekazuje dowód rzeczowy na czas wskazany w upoważnieniu. Zgodnie $\mathrm{z}$ regułą ekonomii procesowej, przewidzianą w ust. 4 tego artykułu, dostęp do dowodu rzeczowego, o którym mowa w ust. 3, nie może utrudniać postępowania karnego ani wpływać na zmniejszenie wartości tego dowodu dla prowadzonego postępowania.

W ujęciu zaproponowanym w projekcie przy ministrze właściwym do spraw wewnętrznych (zob. art. 1 ust. 4 projektu) powstanie Komisja do spraw dokumentów publicznych (art. 49 ust. 1 projektu). Założona rola Komisji będzie sprowadzać się do pomocy ministrowi właściwemu ds. wewnętrznych przy realizacji zadań, o których mowa w art. 3 ust. 1 pkt 1-8 projektu (art. 3 ust. 2 projektu). Chodzi tu o udzielanie pomocy ministrowi w realizacji części zadań ministra nałożonych na niego przepisami projektowanej ustawy, do których należeć mają:

- branie udziału w procedurze opracowywania wzoru dokumentu publicznego,

- analizowanie przypadków fałszerstw dokumentów publicznych,

- inicjowanie zmian zabezpieczeń dokumentów publicznych przed fałszerstwem,

- ocena jakości wydawanych dokumentów publicznych, o których mowa w art. 5 ust. 2 pkt $1-28$ projektu,

- monitorowanie zmian zachodzących na świecie w dziedzinie zabezpieczeń dokumentów przed fałszerstwem,

- współpraca z międzynarodowymi instytucjami i organizacjami zajmującymi się ochroną i zabezpieczaniem dokumentów publicznych przed fałszerstwem,

- publikowanie w Rejestrze Dokumentów Publicznych informacji o wzorach dokumentów publicznych,

- podejmowanie działań mających na celu podnoszenie poziomu edukacji w zakresie wiedzy o możliwościach i sposobach rozpoznawania fałszywych dokumentów publicznych.

Zapewnienie dostępu do dowodów rzeczowych w postaci sfałszowanych dokumentów publicznych dla członków Komisji wydaje się niezbędne dla skutecznego wsparcia ministra właściwego do spraw wewnętrznych w realizacji obowiązków przewidzianych zwłaszcza w pkt $2-5$ oraz 8 art. 3 ust 1 projektu.

Zgodnie z art. 49 ust. 3 projektu w skład Komisji wejdą:

- siedmiu członków powołanych spośród osób wykonujących obowiązki służbowe w ministerstwie ds. wewnętrznych,

- do piętnastu członków powołanych spośród pracowników jednostek organizacyjnych nadzorowanych przez ministra, funkcjonariuszy lub pracowników 
delegowanych przez Komendanta Głównego Policji, Komendanta Głównego Straży Granicznej oraz Szefa Agencji Bezpieczeństwa Wewnętrznego na czas niezbędny do wykonywania zadań,

- do pięciu członków powołanych spośród ekspertów innych podmiotów zajmujących się dokumentami publicznymi.

Zakłada się, że przewodniczący i zastępca przewodniczącego Komisji będą mieć co najmniej 5-letnie, udokumentowane doświadczenie z zakresu technicznych badań dokumentów lub co najmniej 5-letnie, udokumentowane doświadczenie związane z projektowaniem systemów zabezpieczeń dokumentów (art. 49 ust. 4 projektu). Trzech członków Komisji, o których mowa w ust. 3 pkt 1, oraz członkowie, o których mowa w ust. 3 pkt 2, będą mieć co najmniej 2-letnie, udokumentowane doświadczenie, o którym mowa w ust. 4 . (art. 49 ust. 5 projektu). Z kolei wobec dwóch członków Komisji, o których mowa w ust. 3 pkt 1, wprowadza się wymóg posiadania wykształcenia wyższego oraz co najmniej 5-letniego doświadczenie zawodowego w administracji publicznej (art. 49 ust. 6 projektu).

$\mathrm{Z}$ kolei desygnaty pojęcia „organ dysponujący dowodem rzeczowym w postaci sfałszowanego dokumentu publicznego", o którym mowa w art. 40 ust. 3 projektu, będą zmieniać się w zależności od etapu, na którym będzie znajdować się prowadzone postępowanie karne. Na jego etapie przygotowawczym organem prowadzącym tzw. postępowanie przygotowawcze jest prokurator, a w zakresie przewidzianym w ustawie także Policja lub inny organ (art. $298 \$ 1$ Kodeksu postępowania karnego). Na etapie postępowania sądowego będzie nim sąd.

\section{- Analiza art. 40 ust. 3 i 4 przepisów projektu na gruncie prawnokarnych reguł dostępu do materiałów postępowania karnego}

W obowiązującym stanie prawnym dostęp do materiałów zebranych w aktach prowadzonego postępowania jest limitowany, zależy od etapu postępowania oraz roli procesowej uczestnika. Dla przykładu osoba podejrzana i jej pełnomocnik mogą zapoznać się - na ich wniosek - ze zgromadzonymi w śledztwie (dochodzeniu) materiałami $\mathrm{w}$ drodze przejrzenia akt dopiero $\mathrm{w}$ końcowej fazie postępowania przygotowawczego przed jego zamknięciem i skierowaniem aktu oskarżenia do sądu (art. $321 \$ 1$ Kodeksu postępowania karnego). Organ będący gospodarzem postępowania, zwłaszcza na etapie postępowania przygotowawczego, kierując się strategią prowadzonego postępowania, zazwyczaj niesłychanie oszczędnie dzieli się zebraną wiedzą procesową. Ustawodawca przewidział jednocześnie na gruncie Kodeksu karnego rozwiązania ukierunkowane na ochronę dostępu do informacji procesowych. Przy tej okazji należy zwrócić uwagę przede wszystkim na przepis art. $241 \$ 1$ Kodeksu karnego, według którego karane będzie publiczne rozpowszechnianie - bez zezwolenia - wiadomości $\mathrm{z}$ postępowania przygotowawczego, zanim zostały ujawnione $\mathrm{w}$ postępowaniu 
sądowym. Jest to przestępstwo powszechne, którego dopuścić może się każdy, a więc nie tylko uczestnik postępowania, ale każda osoba, która powzięła informacje na temat materiałów procesowych zebranych w takim postępowaniu. Za ten czyn przewidziano karę grzywny, ograniczenia wolności albo pozbawienia wolności do lat 2. Nie stanowi zatem przestępstwa rozpowszechnianie publicznie wiadomości z postępowania przygotowawczego w przypadku, gdy sprawca miał odpowiednie zezwolenie pochodzące od uprawnionego organu (np. prokuratora), a po wpłynięciu aktu oskarżenia do sądu - od sądu ${ }^{22}$. Jak zauważył Wojewódzki Sąd Administracyjny w Gdańsku w wyroku z 14 stycznia 2015 r., sygn. akt I SA/Gd 1250/14: Niezgodne z prawem jest takie działanie, które polega na nieuprawnionym ujawnieniu informacji z postępowania przygotowawczego tak, że stana się one dostępne dla bliżej nieokreślonego kręgu osób. Z taka sytuacją nie mamy do czynienia wówczas, gdy informacje z postępowania przygotowawczego sa przekazywane organom podatkowym, na potrzeby prowadzonego postępowania ${ }^{23}$.

Z kolei zgodnie $\mathrm{z}$ art. $241 \$ 2$ Kodeksu karnego tej samej karze podlega ten, kto rozpowszechnia publicznie wiadomości z rozprawy sądowej prowadzonej z wyłączeniem jawności. Odmiennie jednak niż w art. $241 \S 1$, na gruncie art. $241 \S 2$ nie użyto określenia „bez zezwolenia”, co należy interpretować w ten sposób, że tajemnica rozprawy niejawnej ma charakter bezwzględny i nie może być uchylona ${ }^{24}$.

Przewidziany w projekcie ustawy przepis art. 40 ust. 3 daje podstawę do tego, aby organ prowadzący postępowanie umożliwił upoważnionemu członkowi Komisji dostęp do dowodu rzeczowego w postaci sfałszowanego dokumentu. W konsekwencji realizacji tego uprawnienia członek Komisji uzyska w tym zakresie dostęp do materiałów procesowych. Będzie to jednak dostęp za zezwoleniem uprawnionego organu, co zasadniczo wyłącza bezprawność jego działania, czyniąc je legalnym. Przepis art. 40 ust. 3 projektu będzie pełnił tu rolę swoistego kontratypu dla działań członków Komisji, jako podmiotów trzecich na gruncie prowadzonego postępowania karnego, co do zasady legalizując je. Tym bardziej przepis ten powinien zostać ukształtowany precyzyjnie. Pewnym deficytem tego uregulowania, jaki może przynieść negatywne skutki w praktyce jego stosowania, jest brak określenia celu działania członka Komisji, jak również brak bliższego określenia na czym polegać ma „dostęp do dowodu” i co z pozyskaną informacją będzie mógł prawnie uczynić członek Komisji. Jeśli chodzi o identyfikację celu jego działania, można zapewne posiłkować się katalogiem zadań przypisanych pośrednio Komisji jako organowi wsparcia w realizacji obowiązków nałożonych przez

\footnotetext{
M. Mozgawa, Komentarz aktualizowany do art. 241 Kodeksu karnego, LEX.

LEX nr 16681210.

24 B. Kunicka-Michalska, Art. 241 KK [w:] A. Wąsek, R. Zawłocki, Kodeks karny. Część szczególna. Komentarz do artykułów 222-316, t. II, 2010, s. 318, Legalis; zob. też R.A. Stefański, Tajemnica przesłuchania $z$ wyłączeniem jawności, „Prokuratura i Prawo" 2003 , nr 11, s. 37.
} 
projekt ustawy na ministra (zob. zwłaszcza art. 3 ust. 1 pkt $2-5 \mathrm{w}$ związku z ust. 2 projektu). Natomiast pozostaje wątpliwość, czy dyspozycja art. 40 ust. 3 projektu nie została ujęta zbyt wąsko w zestawieniu z kryminalizacją zawartą w art. 241 Kodeksu karnego, gwarantując członkowi Komisji jedynie dostęp do dowodu, ale już bez, przynajmniej wprost, odniesienia się do tego, co z informacją zdobytą dzięki zrealizowaniu dostępu do dowodu, będzie mógł uczynić. Nie jest jasne w szczególności, czy członek Komisji będzie mógł podzielić się nią z innymi członkami Komisji. Na konieczność rozróżnienia między prawnymi konsekwencjami udostępnienia akt postępowania i rozpowszechnianiem uzyskanych na tej podstawie wiadomości zwrócił uwagę Sąd Najwyższy ${ }^{25}$, wskazując, że udostępnienie akt postępowania przez organ prowadzący postępowanie czy też udzielenie określonej informacji pochodzącej z takiego postępowania, niezależnie od trybu, w jakim zostało dokonane, i statusu podmiotu, któremu udostępniono akta lub udzielono informacji, nie jest równoznaczne z zezwoleniem na publiczne rozpowszechnianie uzyskanych w taki sposób wiadomości pochodzących z postępowania.

Warto jednocześnie zaznaczyć, że projektowany w art. 40 ust. 3 dostęp do materii prowadzonego postępowania karnego w postaci dowodu rzeczowego nie jest rozwiązaniem precedensowym na gruncie obowiązującego systemu prawa. Dla przykładu w postępowaniu immunitetowym, regulowanym przepisami ustawy z 9 maja 1996 r. o wykonywaniu mandatu posła i senatora (t.j. Dz.U. 2016, poz. 1510, ze zm.), przewiduje się nawet szerzej zakreślony instrument, polegający na udostępnieniu przez sąd lub prokuraturę całych akt postępowania na żądanie Marszałka Sejmu lub Marszałka Senatu, wyrażone w związku z postępowaniem sejmowym lub senackim o wyrażenie zgody na pociągnięcie do odpowiedzialności karnej odpowiednio posła lub senatora (art. 7c ust. 3), bądź też wyrażenie zgody na ich zatrzymanie lub aresztowanie (art. 10 ust. $6 \mathrm{w}$ związku $\mathrm{z}$ art. $7 \mathrm{c}$ ust. 3).

Zaletą omawianego rozwiązania normatywnego z art. 40 ust. 3 projektu, którą należy w tym miejscu wyeksponować, jest pragmatyczne powiązanie przyznania dostępu do dowodu z zasadami ekonomii procesowej. W przedstawionym ujęciu gwarancja dostępu do dowodu rzeczowego jest warunkowana celami prowadzonego postępowania karnego i nie może ich przesłaniać, $w$ tym sensie, że nie może utrudniać postępowania karnego ani wpływać na zmniejszenie wartości dowodu dla prowadzonego postępowania (art. 40 ust. 4 projektu).

\section{Wnioski}

- W zakresie, w jakim projekt zmierza do wyłączenia określonych kategorii druków i dokumentów spod regulacji dyrektywy 2014/24, może on zostać

25 Uchwała SN z 21 października 2003 r., sygn. akt I KZP 29/03. 
uznany za niezgodny z dyrektywą 2014/24, w szczególności z art. 1 w związku $\mathrm{Z}$ art. 15 ust. 2.

- Z uwagi na znaczenie rozstrzygnięcia przez TSUE sprawy Komisja v. Republika Austrii, sygn. akt C-187/16, dla oceny zgodności opiniowanego projektu z prawem UE zaleca się zawieszenie prac nad projektem do czasu wydania wyroku przez TSUE (planowana data wydania wyroku: 20 marca 2018 r.).

- Na gruncie ujęcia projektowanego art. 40 ust. 3 rodzi się wątpliwość, czy dyspozycja tego uregulowania nie została ujęta zbyt wąsko w zestawieniu z zakazem karnym zawartym w art. 241 Kodeksu karnego. Członkowi Komisji gwarantuje się dostęp do dowodu, ale już bez odniesienia się do tego, co będzie mógł uczynić z informacją zdobytą dzięki zrealizowaniu tego dostępu. Nie jest jasne w szczególności, czy członek Komisji będzie mógł podzielić się nią $\mathrm{z}$ innymi członkami Komisji.

- Zaletą projektowanego rozwiązania normatywnego z art. 40 ust. 3 jest pragmatyczne powiązanie przyznania dostępu do dowodu z zasadami ekonomii procesowej. Projekt zakłada, że gwarancja dostępu do dowodu rzeczowego jest warunkowana celami prowadzonego postępowania karnego i nie może ich przesłaniać, tzn. utrudniać postępowania karnego ani wpływać na zmniejszenie wartości dowodu dla prowadzonego postępowania (art. 40 ust. 4 projektu).

\section{Bibliografia}

Arrowsmith S., The Law of Public and Utilities Procurement, London 2014.

Kunicka-Michalska B., Art. 241 KK [w:] Kodeks karny. Część szczególna. Komentarz do artykułów 222-316, t. II, red. A. Wąsek, R. Zawłocki, Warszawa 2010.

Mozgawa M., Komentarz aktualizowany do art. 241 Kodeksu karnego, LEX.

Stefański R.A, Tajemnica przesłuchania z wyłączeniem jawności, „Prokuratura i Prawo” 2003, nr 11. 